\title{
QUANTITATIVE PSYCHOLOGY CURRICULUM DESIGN A CASE STUDY AT THE FACULTY OF PSYCHOLOGY SYARIF HIDAYATULLAH STATE ISLAMIC UNIVERSITY JAKARTA
}

\author{
Bambang Suryadi \\ Asosiasi Bimbingan dan Konseling Indonesia \\ bangs1970@gmail.com
}

\begin{abstract}
The need for quantitative psychology in the 21st century is an urgent need for Muslim psychologists to compliment what has been done in term of normative qualitative study. The weakness of Muslims psychologists in mastering the quantitative psychology results in the difficulty of measuring psychological dimensions, such as the dimensions of gratitude, tolerance and so forth. This paper aims to describe the curriculum design of quantitative psychology and the application of the curriculum in teaching and learning process at the Faculty of Psychology Syarif Hidayatullah State Islamic University Jakarta. This study used qualitative method in gathering and analyzing the data. The findings of the study indicates that the concrete activities of quantitative psychology can be initiated by developing psychological instruments measuring psychological variables such as patience, gratitude, tolerance, religiosity, spiritual awareness, spiritual commitment, and spiritual intelligence.
\end{abstract}

Keywords: Measurement, Religiosity, Commitment, Gratitude, Tolerance, Patience.

\begin{abstract}
Abstrak
Kebutuhan terhadap psikologi kuantitatif pada abad ke-21 merupakan kebutuhan mendesak bagi para psikolog Muslim untuk melengkapi apa yang telah mereka lakukan dalam hal penelitian kualitatif normatif. Kelemahan para psikolog Muslim dalam menguasai psikologi kuantitatif berdampak terhadap kesulitan untuk melakukan pengukuran dimensi psikologis, seperti dimensi syukur, toleransi dan sebagainya. Tulisan ini bertujuan untuk menggambarkan desain kurikulum psikologi kuantitatif dan penerapannya dalam proses belajar mengajar di Fakultas Psikologi Universitas Islam Negeri (UIN) Syarif Hidayatullah Jakarta. Penelitian ini menggunakan metode kualitatif dalam mengumpulkan dan menganalisis data. Temuan penelitian menunjukkan bahwa bentuk kegiatan yang kongkrit dalam mengembangkan psikologi kuantitatif berbasis keislaman dapat dimulai dari pengembangan instrumen untuk mengukur variabelvariabel psikologis seperti kesabaran, syukur, toleransi, religiusitas, kesadaran spiritual, komitmen spiritual, dan kecerdasan spiritual.
\end{abstract}

Kata Kunci: Pengukuran, Religiusitas, Komitmen, Syukur, Toleransi,

Sabar 
Diterima: 26 Oktober 2014 2014

Disetujui: 26 November 2014
Direvisi: 18 November

5

9 


\section{BACKGROUND}

Many psychological studies have been conducted in Muslim world using the qualitative method and yielded important information. Most of those studies make the Qur"an, Hadith, and Islamic classical literature as the main sources of the study. The results of those studies have colored the study of psychology not only in the Muslim world but also in non-Muslims countries (the West).

The need for quantitative psychology in the 21st century is an urgent need for Muslim psychologist to compliment what has been done in term of normative qualitative study. The use of quantitative technique is aimed at making their study results more widely accepted. Unfortunately empirical quantitative study, since the 19th century was dominated by Western psychologists. Muslim psychologists are left behind in terms of usage statistics with the various types of software, such as SPSS, MPLUS, LISREL, WINSTEP and so on.

The weakness of Muslims psychologists in mastering the quantitative psychology results in the difficulty of measuring psychological dimensions, such as the dimensions of gratitude, religiosity, spiritual awareness, patience, tolerance and so forth.

This paper aims to describe the curriculum of the Faculty of Psychology Syarif Hidayatullah State Islamic University Jakarta in designing quantitative psychology and the application of the curriculum in teaching and learning process. More specifically this study is to answer the following questions:

1. What is the importance of quantitative psychology?

2. How is the curriculum design of quantitative psychology?

3. What conditions are necessary to strengthen the quantitative psychology?

4. What obstacles encountered in implementing the quantitative psychology curriculum?

5. What are the solutions for these shortcomings?

The results of this study are expected to be a model or benchmark for the faculty of psychology in developing quantitative psychology. By doing so it is expected that the research in psychology will receive worldwide recognition. 
60 


\section{BRIEF HISTORY OF THE FACULTY OF PSYCHOLOGY}

The historical development of the faculty of psychology in Indonesia can be traced back to 1960s and classified into two types. First is the faculty of psychology at the universities under the Ministry of Education and Culture. Second is the faculty of psychology at the Islamic university under the Ministry of Religious Affairs. In July 1, 1960, the first faculty of psychology was established in University of Indonesia. The following year, in September 1, 1961, the Faculty of Psychology at Padjajaran Univerisity was founded. Five years later (January 8, 1965), the Faculty of Psychology at University of Gadjah Mada was established. The three faculties are considered as the pioneers in developing psychology in Indonesia.

Of the three faculties of psychology as mentioned above, the Faculty of Psychology UGM has strength in terms of quantitative psychology. This is evidenced by the lecturers who are experts in the field of quantitative psychology such as the late Sutrisno Hadi, the late Soemadi Suryabrata, and Masrun. However, since the absence of the prominent two scholars (the late Sutrisno Hadi dan the late Soemadi Suryabrata), the emphasis of quantitative psychology at UGM is weakened.

Psychology study program within UIN Syarif Hidayatullah Jakarta was established in 1995. It was attached to the Faculty of Teacher Training (Tarbiyah) and concentrating on educational psychology. Along with the transformation of IAIN to become UIN in 2002, the psychology study program changed its status as the Faculty of Psychology. This is the first non-Islamic study program within the university and later on it was followed by the establishment of the faculty of science and technology, the faculty of economics, and the faculty of medicine and health sciences. Faculty of Psychology has been accredited by the National Accreditation Board for Higher Education or BAN-PT (Umar, 2011).

Following UIN Jakarta, other UINs in Indonesia also open the faculty of psychology, such as UIN Malang, UIN Yogyakarta, UIN Bandung, and UIN Riau. The newly established faculties of psychology is still in the process of seeking its own strength identity and distinctive advantages. Most of these faculties try to develop Islamic psychology through the concept of integration of knowledge. 
Since 2009, the Faculty of Psychology UIN Jakarta developed quantitative psychology under the expertise of Jahja Umar, Ph.D who has been elected as the Dean by the faculty senate members for the period 2009- 
2013. His area of research interest is in measurement and research methodology. Prior to his service at the faculty, he has a lot birocratic experiences in both the Ministry of Education and Culture and the Ministry of Religious Affairs. He was Head of the Center for National Testing in Education (Pusat Penilian Pendidikan), the Ministry of Education and Culture for 14 years. $\mathrm{He}$ is also the founding father of the Indonesian Association for Educational Evaluation (HEPI-Himpunan Evaluasi Pendidikan Indonesia) established in November 19, 2000 in Yogyakarta.

To give brief information on the faculty of psychology UIN Jakarta, it is important to present about the vision, mission, and goal of the study program.

\section{Vision and mission statement}

The vision of the faculty is clearly spelled out to be one of leading faculties of psychology in Indonesia that integrates modern psychology, Islamic values, and Indonesianness. The faculty mission is to produce bachelor in psychology who is excellent, competitive, and productive with good Islamic character in the research and development and in the application of psychology (Umar, 2011).

Given the above vision and mission statement, the ultimate goal of education at the Faculty of Psychology UIN Jakarta is to develop a comprehensive intelligence (spiritual, intellectual, social, emotional, adversity, and physical). In this regard, the educational program of psychology at the Faculty of Psychology UIN Jakarta aims to create graduates who have the following competencies:

1. Personal and Social: Faithful, devoted and noble character; have a passion to learn and work; have an empathy, ability to cooperate and communicate effectively.

2. Scientific Ability: The scientific competence related to the mastery of psychological theories from a variety of approaches, Islamic values, and interdisciplinary; ability to think scientifically; using Indonesian, Arabic, and English language skills in scientific activities.

3. Research: The ability to do research by applying appropriate research methods; the ability to operate statistical software.

4. Assessment: Having an understanding of the psychological assessment which includes understanding and using of test and non-test equipment.

5. Intervention: Having designing skills for training, discussion facilitator, guidance and counseling. 
62 
To achieve the competencies, the curriculum design of the Faculty of Psychology UIN Jakarta integrates modern psychology, Islamic values, and Indonesian contexts, with a load of 156 credits of study (Hidayat, 2011).

Starting in 2010 the Faculty of Psychology UIN Jakarta opened Master of Science in Psychology Program with three specializations, namely Educational Psychology, Industrial and Organizational Psychology, and Psychometric. The program has four semesters, in the fourth semester students are required to write a thesis. Maximum limit of the study is six semesters.

The Master of Science in Psychology Program aims to produce a graduate who has the following competencies:

1. Ability to conduct research and development in education

2. Ability to apply and develop organizational change

3. Ability to implement and develop the measurement and assessment

instruments in psychology and education (Suryadi, 2011).

In short, the distinctive quality of the Faculty of Psychology UIN Jakarta in its early age is to become a center for excellence in quantitative psychology.

\section{THE IMPORTANCE OF QUANTITATIVE PSYCHOLOGY}

Before discussing the significance of quantitative psychology in the present world, it is important to know about the quantitative psychology. Edward (2011) upon reviewing several literatures on quantitative psychology comes up with the following definitions of quantitative psychology.

1. Quantitative Psychology is the development and application of mathematical models, statistical methods, and measurement in psychological research.

2. Quantitative and measurement psychologists focus on methods and techniques for designing experiments and analyzing psychological data. Some develop new methods for performing analyses; others create research strategies to assess the effect of social and educational programs and psychological treatment. They develop and evaluate mathematical models for psychological tests. They also propose methods for evaluating the quality and fairness of the tests 
3. Quantitative psychology develops psychological theory in relation to mathematics and statistics. Psychological research requires the elaboration of existing methods and the development of new concepts, so 
that quantitative psychology requires more than "applications" of statistics and mathematics.

4. Quantitative psychology is the study of methods and techniques for the measurement of human attributes, the statistical and mathematical modelling of psychological processes, the design of research studies, and the analysis of psychological data.

5. Quantitative psychology is central to all aspects of psychology: science, education, public interest, and practice. This essential role of quantitative psychology is reflected in the fact that Division 5 - Evaluation, Measurement, and Statistics - is one of the Charter Divisions of the American Psychological Association (APA).

From those definitions, it is clear that quantitative psychology has two

major subfields, psychometrics and mathematical psychology, which are associated most to statistics and mathematics. Research in psychometrics develops statistical procedures for the problems of psychology, such as psychological scaling, and testing. Research in mathematical psychology develops of novel mathematical models that describe psychological processes.

Given the above mentioned definitions of quantitative psychology, the writer argues that the need for quantitative psychology in the 21st century is an urgent need for Muslim psychologist to compliment what has been done in term of normative qualitative study. The use of quantitative technique is aimed at making their study results more widely accepted. The weakness of Muslims psychologists in mastering the quantitative psychology results in the difficulty of measuring psychological dimensions, such as the dimensions of gratitude, religiosity, spiritual awareness, tolerance and so forth.

Another reason for having quantitative psychology is to eliminate the major error in research. Commonly speaking, there are four major errors in research and evaluation. They are (1) sampling error, (2) measurement error, (3) specification error, and (4) randomization error. The four types of errors can be solved by introducing quantitative psychology course works such as psychometric, statistics, and research methodology as major $r$ coursework in psychology curriculum. 
64 


\section{THE CURRICULUM DESIGN FOR QUANTITATIVE PSYCHOLOGY}

There are two level of education program at the faculty of psychology, both

are undergraduate program and postgraduate program. As for undergraduate program, students are required to complete about 154 credit hours within a minimum of 8 semesters and maximum of 14 semesters.

Of 154 credit hours, 20 credit hours are allocated for quantitative psychology course works as can be seen in the following table.

Table 1

Quantitative Psychology Course Work For Undergraduate Program

\begin{tabular}{clc}
\hline No & \multicolumn{1}{c}{ Coursework } & $\begin{array}{c}\text { Credit } \\
\text { Hours }\end{array}$ \\
\hline 1 & Statistics 1 & 3 \\
2 & Research Methodology 1 & 3 \\
3 & Statistics 2 & 3 \\
4 & Research Methodology 2 & 3 \\
5 & Psychometrics & 3 \\
6 & Statistics 3 & 2 \\
7 & Construction of psychological test & 3 \\
& Total & 20 \\
\hline
\end{tabular}

In general the content of Statistics 1 covers the descriptive statistics, while the content of Statistics 2 covers the concept of regression and the content of Statistics 3 covers the concepts of factor analysis. Research Methodology 1 is talking about the concept of research methodology, its principles, variables, types and categories. As for Research Methodology 2 its contents are about the research design, sampling technique, validity, and reliability. In Psychometrics, the coursework content is about the evaluation, assessment, measurement, validity and reliability of the instrument. It also covers the item and test analysis, and classical test theory.

As for postgraduate program, there are 43 credit hours requirement for completing the program. Of the 43 credit hours, 22 credit hours are allocated for quantitative psychology coursework as can be seen in the following table. 
65 
Table 2

Quantitative Psychology Course Work For Postgraduate Program In Psychometrics

\begin{tabular}{clc}
\hline No & \multicolumn{1}{c}{ Coursework } & $\begin{array}{c}\text { Credit } \\
\text { Hour }\end{array}$ \\
\hline 1 & Classical test theory & 3 \\
2 & Ability test and non-ability test & 4 \\
3 & Sampling technique & 4 \\
4 & Item Response Theory & 4 \\
5 & Non Parametric statistics & 3 \\
6 & Factor Analysis & 4 \\
& Total & 21 \\
\hline
\end{tabular}

In implementing the above curriculum design, the Faculty of Psychology sets the following academic policies. First, the faculty reviewed it"s curriculum in every five years involving both internal and external reviewers. Feedback and recommendation from the reviewers are taken into account to redesign the curriculum by considering the needs and expectations of stakeholders. Second, students of undergraduate and postgraduate are required to write a thesis using quantitative method involving a minimum of 8 variables. These variables include both continuum and categorical variables. As for data analysis, it is highly recommended to use regression, multiple regression, and factor analysis. Thirds, the faculty also founded a Center for Psychological Services in facilitating its students and lecturers to do research in quantitative psychology.

To illustrate the above-mentioned academic policies, the following examples of undergraduate thesis clearly indicate the strength of quantitative psychology at the Faculty of Psychology UIN Jakarta. Study of construct validity for multidimensional intelligence test performance session (Inspirawan, 2011); Study of construct validity of general aptitude test battery (GATB) using confirmatory factor analysis (Afifah, 2011); Psychological factors affecting forgiveness among the victims of house violence (Abdat, 2011); Factors influencing the intention to save at the Syariah Banking System (Priadji, 2011); and Psychological factors affecting the healthy behavior of university students in South Tangerang (Rahmadian, 2011). 
66 


\section{THE NECESSARY CONDITIONS IN STRENGTHENING THE QUANTITATIVE PSYCHOLOGY}

There are certain conditions required in strengthening the quantitative psychology in the faculty of psychology. In the writer"s point of view, the following conditions are necessarily required as a minimum condition for developing quantitative psychology.

1. Student input. Ideally student input for quantitative psychology are graduates from sciences program of upper secondary schools as they have strong foundation in Mathematics and sciences (Biology, Chemistry, and Physics). This does not mean that social program students are not eligible to enroll to the faculty of psychology.

2. Facility. Research finding indicates that facilities availability contributes about 38 percent for the success of academic program at university level. This shows that facilities are important aspect of education. In this matter, laboratory psychology is very important. The Psychology laboratory has a function as a media to train and develop student ability in psychology. The laboratory program consists of practices for psycho diagnostic, counseling, data analysis, research in psychology and psychological measurement. The psychology laboratory has certain instruments, such as psychological test, software for psycho test correction, experimentation instrument, software of statistical data analysis, individual and group counseling room. It is coordinated by a lecturer and assisted by laboratory assistants.

3. Human resources or lecturers. How good the curriculum design is, it is difficult to implement without having enough human resources (lecturers). In the faculty of psychology, teaching staff consists of academics and practitioners of psychology with educational background of Master and Doctor from leading universities at home and abroad. Of the 33 lecturers, five lecturers with doctorate degree (S3) and thirteen lecturers are completing their studies for doctoral program. More than two-thirds of the lecturers under the age of 40 years. This makes it more dynamic faculty with high mobility. The faculty also has two senior academic mentors to provide academic assistance to students in doing the research. 
4. Assessment and evaluation system. Assessment and evaluation system should consider the learning process, assignment, and semester test. This 
condition is meant to have a comprehensive evaluation on student academic performance.

There are many other conditions that need to be provided but not mentioned here. Even though, the above mentioned conditions need to be paid more attention by the faculty members.

\section{OBSTACLES ENCOUNTERED IN IMPLEMENTING THE QUANTITATIVE PSYCHOLOGY CURRICULUM}

1. Lack of faculty of psychology developing quantitative psychology due to the lack of expertise or human resources. The fact that very few school of psychology which offers quantitative psychology is not only the problem of the faculty of psychology in the muslim world but it is also the problem in the global world. This has been expressed by Mark Appelbaum as cited by Clay (2005) as follows:

"There aren't enough of us quantitative people, and many of us are getting to be more senior," says Appelbaum, a psychology professor at the University of California, San Diego. "We're now getting to the point where the first piece of mail we open is the one that has the balance in the retirement account."

Clay further said that Appelbaum's not the only one who's concerned about an extreme shortage of psychologists trained in statistics, measurement and methodology. APA and the field as a whole worry that even as demand for experts in quantitative psychology is soaring, the number of students entering the subspecialty is decreasing. APA and others hope to change that. Many students aren't aware of the field, and those who are often lack mathematical ability or interest. The ever-increasing shortfall means that there aren't enough quantitative psychologists to train the next generation and ensure that all psychologists can properly analyze increasingly sophisticated research.

2. Not interested in studying quantitative psychology. Most students interested in using psychological test of personality, intelligence, traits and so on. Surprisingly only small number of them interested in quantitative psychology. This condition makes them highly dependent on the product of Western psychology in terms of psychological tests. 
68 


\section{CONCLUSION AND RECOMMENDATION}

Based on the previous description of the quantitative psychology, the following conclusion are made.

1. Worries about the lack of experts in quantitative psychology is not only felt by Muslim psychologist, but also felt by psychologists in the Western world, as perceived by the APA in the above discussion.

2. An opportunity to strengthen the quantitative psychology remains open to Muslim psychologists by signing Memorandum of Understanding (MoU) between the faculties of psychology in the Muslim countries like International Islamic University Malaysia (IIUM) and UIN Jakarta. In this matter, the Faculty of Psychology UIN Jakarta is very open to collaboration and cooperation with other psychology faculties in the development of quantitative psychology with maintaining the spirit of Islam.

3. The concrete activities of quantitative psychology can be initiated by developing psychological instruments measuring psychological variables such as patience, gratitude, tolerance, religiosity, spiritual awareness, spiritual commitment, and spiritual intelligence. The next program is to conduct joint research using these instruments and to publish the findings in international journal of psychology.

\section{REFERENCES}

Abdat, Nuran. (2011). Psychological factors affecting forgiveness among the victims of house violence. Unpublished undergraduate thesis. Faculty of Psychology UIN Jakarta.

Claly, R. (2005). Too few in quantitative psychology. Monitor on Psychology.

APA. September. 2005. Vol. 36.No. 38.

Edward, M. (2011). L.L. Thurstone Psychometric Laboratory The University of North Carolina at Chapel Hill. Finding and Defining

Quantitative Psychology.

http://faculty.psy.ohiostate.edu/edwards/documents/APA05Edwards MillsapSym posium. pdf (Retrived on November 21, 2011).

Hidayat, Komaruddin. (2011). Undergraduate Academic Guideline 2011. UIN Jakarta Press. 
Inspirawan, Reza. 2011. Construct Validity for Multidimensional Intelligence Test Performance Session. Unpublished undergraduate thesis. Faculty of Psychology UIN Jakarta. 
Priadji, Vita Widya, (2011). Factors influencing the intention to save at the Syariah Banking System. Unpublished undergraduate thesis. Faculty of Psychology UIN Jakarta.

Rahmadian, Sarah. (2011). Psychological factors affecting the healthy behavior of university students in South Tangerang. Unpublished undergraduate thesis. Faculty of Psychology UIN Jakarta.

Suryadi, Bambang. (2011). Postgraduate Program Prospectus. Faculty of Psychology UIN Jakarta.

Umar, Jahja. (2011). Profile of Faculty of Psychology. UIN Syarif Hidayatullah Jakarta. 